EFFECT OF PREGNANCY ON THE LIPID PROFILE IN EGYPTIAN WOMEN

\title{
Ghada Ibrahim.
}

Cardiology Department, Faculty of Medicine, Zagazig University

\begin{abstract}
Background:Blood lipid concentration increase significantly during pregnancy. The increased progesterone in the $2^{\text {nd }}$ half of pregnancy may act to reset the lipostat in the hypothalamus. There is conflicting evidence for an association between parity and the risk of cardiovascular disease in women. Previous studies have reported a decline in HDL cholesterol up to 10 years after the first pregnancy.Objective: To detect the effect of pregnancy on the lipid profile during normal pregnancy in the different trimesters.Patients andMethods: This study included 100 cases; 80 pregnant women and 20 healthy non-pregnant women matched for age as control. All patients subjected to: Compete history taking and clinical examination, twelve leads resting surface ECG, echocardiography and total Lipid Profile (at the middle of each trimester and 6-12 weeks post-partum) In general, the test performed following 12 hours overnight fast.Results:The total cholesterol and triglycerides were significantly increased from the $1^{\text {st }}$ to the $2^{\text {nd }}$ trimester with further significant increase in the $3^{\text {rd }}$ trimesterand after delivery there were highly significant decrease in both. (TC changed from $196 \pm 18 \mathrm{mg} / \mathrm{dl}$ to $216 \pm 19.3 \mathrm{mg} / \mathrm{dl}$ to $243 \pm 13.5 \mathrm{mg} / \mathrm{dl}$ with $\mathrm{P}<0.05$ then to $187.1 \pm 19.3 \mathrm{mg} / \mathrm{dl}$ with $\mathrm{P}<0.001$, respectively). The LDL cholesterol, HDL cholesterol and VLDL cholesterol were non-significantly changed from the $1^{\text {st }}$ trimester to the $2^{\text {nd }}$ trimester with significant increase in the $3^{\text {rd }}$ trimester and after delivery it was highly significant decreased to the below or near the $1^{\text {st }}$ trimester level(LDLchanged from $119 \pm 9 \mathrm{mg} / \mathrm{dl}$ to $111.9 \pm 11.5 \mathrm{mg} / \mathrm{dl}$ to $123.5 \pm 11.9 \mathrm{mg} / \mathrm{dl}$ with $\mathrm{P}>0.05$ then to $112.6 \pm 13.8 \mathrm{mg} / \mathrm{dl}$ with $\mathrm{P}<0.001$, respectively) (HDL changed from $41.9 \pm 14$ $\mathrm{mg} / \mathrm{dl}$ to $42.8 \pm 15.4 \mathrm{mg} / \mathrm{dl}$, with $\mathrm{P}<0.05$ then to $57.9 \pm 23.1 \mathrm{mg} / \mathrm{dl}$ to $48.6 \pm 25 \mathrm{mg} / \mathrm{dl}$ with $\mathrm{P}<0.001$, respectively) Conclusions: We have demonstrated that normal pregnancy is associated with raised triglycerides and cholesterol. By the third trimester most women have a lipid profile which would be considered highly atherogenic in the non-pregnant state. However this represents a transient disturbance which reverts to normal after delivery. Further studies are needed to determine the risk and cardiovascular effects of disturbed lipid profile during pregnancy especially in multipara women with repeated pregnancy.
\end{abstract}

Keywords: Pregnancy - Lipid profile

Abbreviations:

TG: triglycerides.

TC: total cholesterol.

HDL-C: high density lipoprotein cholesterol.

LDL-C: low density lipoprotein cholesterol.

VLDL-C: very low density lipoprotein cholesterol.

SBP: systolic blood pressure.

DBP: diastolic blood pressure.

HTN: hypertension.

DM: diabetes mellitus.

\section{INTRODUCTION AND AIM OF THE WORK}

R lood lipid concentrations increases Dignificantly during pregnancy. ${ }^{(1)}$ Fat storage occurs primarily during early and midpregnancy. ${ }^{(2)}$ There is some evidence that progesterone, which increases markedly in the second half of pregnancy, may act to reset the lipostat in the hypothalamus. ${ }^{(3)}$ Hypercholesterolemia is an important cause of early atherosclerosis. ${ }^{(4)}$ Nevertheless, there is conflicting evidence for an association between parity and the risk of cardiovascular disease in women. ${ }^{(5)(6)}$ Also, estradiol and progesterone effect on the liver may have some effect. ${ }^{(7)}$ It has been suggested that dyslipidemia during pregnancy might be used to identify women who will develop atherogenic changes later in life. ${ }^{(1)}$ Previous studies have reported a decline in HDL cholesterol up to 10 years after the first pregnancy, independent of weight, central adiposity and selected behavioral changes. ${ }^{(8)}$ Wald and Guckle, ${ }^{(9)}$ observed that the increase in the maternal lipid profile in the third trimester is in response to the maternal switch from carbohydrate to fat metabolism which is an alternative pathway for energy generation due to high energy demand.Also, dyslipidemia may activate the endothelial cells with placentally derived endothelial disturbing factors like lipid peroxides could be regarded as possible contributors for pathogenesis of Pregnancy induced hypertension. ${ }^{(10)}$

The present study was undertaken to elucidate any significant variation in the lipid profile during normal pregnancy in the different trimesters to study the effect of pregnancy on the lipid profile.

\section{MATERIAL AND METHODS}

Patients:This study included 100 cases 80 pregnant women and 20 healthy non-pregnant women matched for age as control. 
Inclusion criteria: Patients included in the study if they are pregnant in the $1^{\text {st }}$ trimester with age ranged from 20 to 40 years old with no history of known heart disease, HTN, DM, smoking or dyslipidemia.

Exclusion criteria: Patients excluded from the study if they had: chronic diseases that may affect the lipid profile, Women who used a medication that could possibly affect the lipid profile, patients with heart disease, as were patients with family history of dyslipidemia, Adolescents ( $<20$ years) and women over age 40 were excluded because of high risk pregnancy. Methods:All patients subjected to the following:

\section{Compete history taking and clinical examination.}

2. Twelve leads resting surface ECG.

3. Transthoracic Echocardiography: to exclude cases with heart disease. 4. Total Lipid Profile: The lipid profiles obtained in the middle of each trimester during pregnancy and 6-12 weeks post-partum. In general, the tests performed following 12 hours overnight fast. Blood was also taken from non-pregnant women and used as control. ${ }^{(11)}$

Statistic:Data were analyzed using SPSS 14 Computer system with calculation of means and standard deviations and comparing the data with paired and unpaired T test and ANOVA teat for analysis of variance for comparing between groups for significant differences.

\section{RESULTS}

This study included 80 pregnant females with age ranged from 20 to 40 years with mean age of $31 \pm$ 4.5 years with no risk factors. There were no significant difference between the patients group and the control group in age, heart rate, SBP, DBP, parity, HTN, DM, Smoking or history of dyslipidemia as in table (1)
In the control group the mean total cholesterol was $190.7 \pm 11.3 \mathrm{mg} / \mathrm{dl}$, LDL-C was $122.6 \pm 15.2$ $\mathrm{mg} / \mathrm{dl}$, HDL-C $45 \pm 10.1 \mathrm{mg} / \mathrm{dl}$, VLDL-C $24.1 \pm$ $2.3 \mathrm{mg} / \mathrm{dl}$ and total triglycerides $129.7 \pm 11.8$ $\mathrm{mg} / \mathrm{dl}$.

The mean total cholesterol was $196 \pm 18 \mathrm{mg} / \mathrm{dl}$ at presentation in the $1^{\text {st }}$ trimester which significantly increased to $216 \pm 19.3 \mathrm{mg} / \mathrm{dl}$ in the $2^{\text {nd }}$ trimester with further significant increase to $243 \mathrm{u} 13.5 \mathrm{mg} / \mathrm{dl}$ in the $3^{\text {rd }}$ trimester and after delivery it was highly significant decreased to the below the $1^{\text {st }}$ trimester level $(187.1 \pm 19.3 \mathrm{mg} / \mathrm{dl})$.

The mean LDL cholesterol was $119 \pm 9 \mathrm{mg} / \mathrm{dl}$ at presentation in the $1^{\text {st }}$ trimester which nonsignificantly decreased to $111.9 \pm 11.5 \mathrm{mg} / \mathrm{dl}$ in the $2^{\text {nd }}$ trimester with significant increase to $123.5 \pm 11.9 \mathrm{mg} / \mathrm{dl}$ in the $3^{\text {rd }}$ trimester and after delivery it was highly significant decreased to the below the $1^{\text {st }}$ trimester level $(112.6 \pm 13.8 \mathrm{mg} / \mathrm{dl})$

The mean HDL cholesterol was $41.9 \pm 14 \mathrm{mg} / \mathrm{dl}$ at presentation in the $1^{\text {st }}$ trimester with no significant changes to $42.8 \pm 15.4 \mathrm{mg} / \mathrm{dl}$ in the $2^{\text {nd }}$ trimester with significant increase to $57.9 \pm 23.1 \mathrm{mg} / \mathrm{dl}$ in the $3^{\text {rd }}$ trimester and after delivery it was highly significant decreased to near the $1^{\text {st }}$ trimester level $(48.6 \pm 25 \mathrm{mg} / \mathrm{dl})$.

The mean VLDL cholesterol was $23 \pm 4 \mathrm{mg} / \mathrm{dl}$ at presentation in the $1^{\text {st }}$ trimester which nonsignificantly changed to $23.5 \pm 3.8 \mathrm{mg} / \mathrm{dl}$ in the $2^{\text {nd }}$ trimester with significant increase to $27.3 \pm 1.9$ $\mathrm{mg} / \mathrm{dl}$ in the $3^{\text {rd }}$ trimester and after delivery it was highly significant decreased to blow the $1^{\text {st }}$ trimester level $(11.3 \pm 5 \mathrm{mg} / \mathrm{dl})$.

The mean total triglycerides was $198 \pm 10 \mathrm{mg} / \mathrm{dl}$ at presentation in the $1^{\text {st }}$ trimester which significant change to $221.1 \pm 11 \mathrm{mg} / \mathrm{dl}$ in the $2^{\text {nd }}$ trimester with significant increase to $295 \pm 53.1 \mathrm{mg} / \mathrm{dl}$ in the $3^{\text {rd }}$ trimester and after delivery it was highly significant decreased to near the $1^{\text {st }}$ trimester level $(211.1 \pm 39.8 \mathrm{mg} / \mathrm{dl})$.

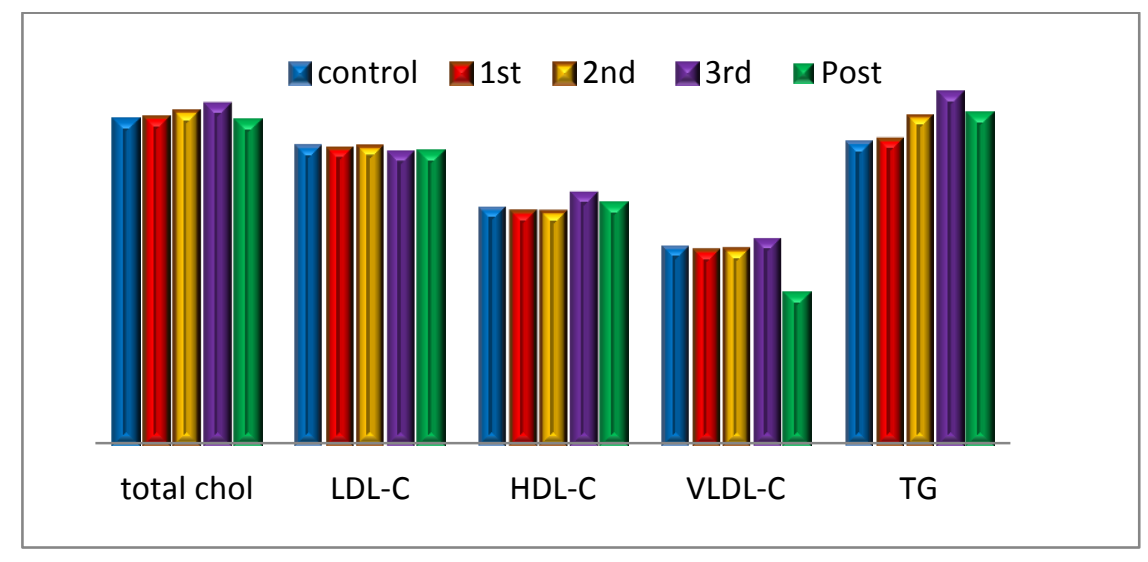


Figure (1): Shows the differences in total lipid profile in control and pregnant females in different stages of pregnancy.

Table (1): The clinical data and risk factors of the study population.

\begin{tabular}{|c|c|c|c|c|c|c|}
\hline \multirow{2}{*}{ Variables } & & \multicolumn{2}{|c|}{ Pregnant } & \multicolumn{2}{|c|}{ Control } & \multirow{2}{*}{$P$} \\
\hline & & \multicolumn{2}{|c|}{$X \pm S D$} & \multicolumn{2}{|c|}{$X \pm S D$} & \\
\hline Age & & \multicolumn{2}{|c|}{$30 \pm 4.5$} & \multicolumn{2}{|c|}{$30 \pm 2.5$} & $>0.05$ \\
\hline$H R$ & & \multicolumn{2}{|c|}{$76 \pm 11$} & \multicolumn{2}{|c|}{$77 \pm 10$} & $>0.05$ \\
\hline$S B P$ & & \multicolumn{2}{|c|}{$132 \pm 8$} & \multicolumn{2}{|c|}{$126 \pm 7$} & $>0.05$ \\
\hline$D B P$ & & \multicolumn{2}{|c|}{$67 \pm 11$} & \multicolumn{2}{|c|}{$69 \pm 8$} & $>0.05$ \\
\hline Variables & & $N$ & $\%$ & $N$ & $\%$ & $P$ \\
\hline \multirow{2}{*}{ Parity } & Nullipara & 20 & 25 & 5 & 25 & $>0.05$ \\
\hline & Multipara & 60 & 75 & 15 & 75 & $>0.05$ \\
\hline \multicolumn{2}{|l|}{ Hist. Oral contraceptive } & 8 & 10 & 3 & 15 & $>0.05$ \\
\hline \multicolumn{2}{|l|}{$H T N$} & 0 & 0 & 0 & 0 & $>0.05$ \\
\hline \multicolumn{2}{|l|}{$D M$} & 0 & 0 & 0 & 0 & $>0.05$ \\
\hline \multicolumn{2}{|l|}{ Smoking } & 0 & 0 & 0 & 0 & $>0.05$ \\
\hline \multicolumn{2}{|l|}{ Dyslipidemia } & 0 & 0 & 0 & 0 & $>0.05$ \\
\hline
\end{tabular}

Table (2): The changes in the lipid profile during pregnancy and after delivery in the study population.

\begin{tabular}{|c|c|c|c|c|c|}
\hline \multirow{2}{*}{ Variables } & Total chol. & $L D L-C$ & $H D L-C$ & $V L D L-C$ & Total TG \\
\hline & $X \pm S D$ & $X \pm S D$ & $X \pm S D$ & $X \pm S D$ & $X \pm S D$ \\
\hline Nonpregnant & $190.7 \pm 11.3$ & $122.6 \pm 15.2$ & $45 \pm 10.1$ & $24.1 \pm 2.3$ & $129.7 \pm 11.8$ \\
\hline$I^{\text {st }}$ trimester & $196 \pm 18$ & $119 \pm 9$ & $42.9 \pm 14$ & $23 \pm 4$ & $138 \pm 10$ \\
\hline$P$ & $>0.05$ & $>0.05$ & $>0.05$ & $>0.05$ & $<0.05$ \\
\hline $2^{\text {nd }}$ trimester & $216 \pm 19.3$ & $123.5 \pm 11.5$ & $42.8 \pm 15.4$ & $23.5 \pm 3.8$ & $200 \pm 11$ \\
\hline $\boldsymbol{P}$ & $<0.05$ & $<0.05$ & $>0.05$ & $>0.05$ & $<0.05$ \\
\hline $3^{\text {rd }}$ trimester & $243 \pm 13.5$ & $111.9 \pm 11.9$ & $57.9 \pm 23.1$ & $27.3 \pm 1.9$ & $295 \pm 53.1$ \\
\hline$P$ & $<0.05$ & $<0.05$ & $<0.05$ & $<0.05$ & $<0.05$ \\
\hline Postpartum & $187.1 \pm 19.3$ & $112.6 \pm 13.8$ & $48.6 \pm 25$ & $11.3 \pm 5$ & $211.1 \pm 39.8$ \\
\hline$P$ & $<0.05$ & $<0.05$ & $<0.05$ & $<0.05$ & $<0.05$ \\
\hline
\end{tabular}

\section{DISCUSSION}

In this study, the total cholesterol level increased significantly in the $2^{\text {nd }}$ and $3^{\text {rd }}$ trimester, this result is in accordance with Jayanta et al, (10) Who observed that the concentration of serum total cholesterol, serum triglyceride, HDL cholesterol and LDL cholesterol in normal pregnant women increases with increasing gestational age.

In our study there was significant fall in LDL-C level in $3^{\mathrm{rd}}$ trimester of normal pregnancy, this result is in accordance with Jayanta et al, (10) which stated that this decrease in LDL-C could be explained by hyperestrogenaemia.

In our study the serum triglycerides level increased starting from the $1^{\text {st }}$ trimester with highly significant elevation by the $2^{\text {nd }}$ trimester and increased markedly by the $3^{\text {rd }}$ trimester. These results are in agreement with Chiang et al, ${ }^{(11)}$ \& Ray et al, ${ }^{(12)}$ who showed that the most dramatic damage in the lipid profile in normal pregnancy is serum hypertriglyceridemia, which may be as high as two to three folds in the third trimester over the levels in nonpregnant women. The 
principle modulator of this hypertriglyceridemia is estrogen as pregnancy is associated with hyperoestrogenaemia. Estrogen induces hepatic biosynthesis of endogenous triglycerides, which is carried by VLDL. ${ }^{(13)}$ This process may be also modulated by hyperinsulinism found in pregnancy. ${ }^{(14)}$

This rise in TG, TC, and LDL may be due to an increase in hepatic lipase activity and a decrease in lipoprotein lipase activity. Hepatic lipase is responsible for the increased synthesis of triglycerides at the hepatic level, whereas the decreased activity of lipoprotein lipase is responsible for the decreased catabolism at the adipose tissue level, the net effect of which will be an increase in circulating TGs. The second step of uptake of the remnant chylomicrons by the liver is delayed so it leads to accumulation of TGs in plasma. ${ }^{(15)}$

In our study, the mean value of HDL-C was

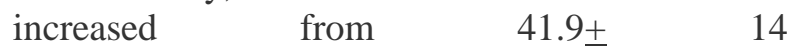
$57.9 \pm 23.1 \mathrm{mg} / \mathrm{dl}$ about $28.7 \%$ higher in the third trimester of normal pregnancyover the nonpregnant women, with statistically significant difference.This result is in accordance with Jayanta et al, ${ }^{(10)}$ and Mankuta et al, ${ }^{(16)}$.

In present study, serum VLDL-C level rose significantly $(\mathrm{P}<0.05)$ in the third trimester of pregnancy in comparison to non-pregnant women, which is perhaps due to hypertriglyceridemia leading to enhanced entry of VLDL that carries endogenous triglyceride into circulation. These results are in accordance with Teichmann et al, ${ }^{(17)}$ \& Knopp et al, ${ }^{(18)}$ and Potter and Netel, ${ }^{(19)}$ whom reported that VLDL-C might rise up to 2.5 folds at term over the pre-pregnancy level.

Finally the return of all lipids profile including total cholesterol, LDL-C, HDL-C, VLDL-C and triglycerides level to normal within 6-12 weeks after delivery indicated that these changes in the lipid profile during pregnancy are due to the hormonal changes that occur with pregnancy.

\section{CONCLUSION}

In conclusion, we have demonstrated that normal pregnancy is associated with raised triglycerides and cholesterol. By the third trimester most women have a lipid profile which would be considered highly atherogenicin the non-pregnant state. Although this represents a transient disturbance which reverts to normal after delivery, the long-term consequences of multiple pregnancies on LDL subfraction and lipid profile are unknown. Further studies are needed to determine if certain women are at increased risk of cardiovascular disease later in life because of the effects of repeated pregnancy on their lipid profile.

\section{REFERENCE}

1. Brizzi P, Tonolo G, Esposito F, et al. Lipoprotein metabolism during normal pregnancy. Am J ObstetGynecol, 1999;181(2):430-4.

2. Pipe N: Fat morphology and adiposity in pregnancy. Midwife Health Visit Community Nurse, 1979;15(7):271-4.

3. Rössner S and Ohlin A: Pregnancy as a risk factor for obesity. lessons from the Stockholm Pregnancy and Weight Development Study. Obes Res, 1995; 3 (Suppl 2):267s-275s.

4. Smith F: Hyperlipidemia and premature arteriosclerosis. Lipids, 1978; 13(5):375-7. 5. Ness R, Schotland $H$, Flegal $K$ et al. Reproductive history and coronary heart disease risk in women. Epidemiol Rev, 1994;16 (2):298314.

6. Green A, Beral V and Moser K: Mortality in women in relation to their childbearing history. BMJ, 1988; 297(6645):391-5.

7. Desoye G, Schweditsch $\mathrm{M}$ and Pfeiffer K: Correlation of hormones with lipid and lipoprotein levels during normal pregnancy and postpartum. J Clin Endocrinology M, 1987; 64:704.

8. Gunderson E, Lewis C, Murtaugh M et al. Longterm plasma lipid changes associated with a first birth: the Coronary Artery Risk Development in Young Adults study. Am J Epidemiol, 2004;159(11):1028-39.

9. Wald, N. and Guckle, H.: Comparative study of lipid profile of normal pregnant women in the different trimesters. Br. Med. J., 1988; 297: 883 - 887.

10. Jayanta D, Ananda Kumar A and Saha K: study of serum lipid profile in pregnancy induced hypertension .Indian Journal of Clinical Biochemistry, 2006; 21 (2) 165-168

11. Chiang A, Yang M, Hung J. et al. Alterations of serum lipid levels and their biological relevances during and after pregnancy. Life Sci. 1995; 56(26), 2367-75.

12. Ray J, Diamond P, Singh G. et al. Brief overview of maternal triglycerides as a risk factor for preeclampsia. Br J ObstetGynaecol; 2006: 113: 37986.

13. Ekhator $\mathrm{C}$ and Ebomoyi $\mathrm{M}$ : Blood glucose and serum lipid profiles during pregnancy. African Journal of Diabetes Medicine, 2012; Vol 20 No 1 May

14. Adegoke O, Iyare $\mathrm{E}$ and Gbenebitse S: Fasting plasma glucose and cholesterol levels in pregnant Nigerian women. Niger. Postgrad.Med. J. 2003; 10 (1), 32-6.

15. Rubina A and Tabassum M: Pre-eclampsia and lipid profile. Pak J Med Sci; 2007; 23: 751-4.

16. Mankuta D, Elami-Suzin M, Elhayani et al. Lipid profile in consecutive pregnancies. Lipids in Health and Disease, 2010; 9:58: 133.

17. Teichmann A, Wieland H, Cremer P et al. Serum lipid and lipoprotein concentrations in pregnancy and at onset of labour in normal and complicated 
pregnancies caused by hypertensive gestosis and fetal growth retardation. GeburtshilfeFrauenheilkd (Germany, West); 1988; 48 (3), 134-9.

18. Knopp R, Warth M, Charles D et al. Lipoprotein metabolism in pregnancy, fat transport to the fetus and the effects of diabetes, Biol. Neonate (Switzerland); 1986; 50 (6), 297-317.

19. Potter $\mathbf{J}$ and Netel P: The hyperlipidaemia of pregnancy in normal and complicated pregnancies. Am. J. Obstet. Gynaecol. (United States); 1979; 133(2), 165-70. 


\section{تأثير الحمل على صورة دهون الام في المرأة المصرية}

هناكبعض الأدلة على أنهزمون البروجسترونالذى يزداد بشكل ملحوظفي النصفالثاني من الحمل، قد يؤدى إلى إعادة ضبط مركز تنظئي الدهون فئ في

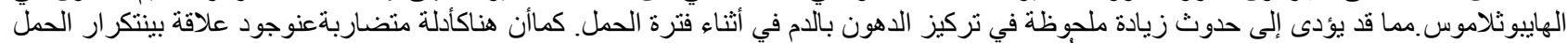

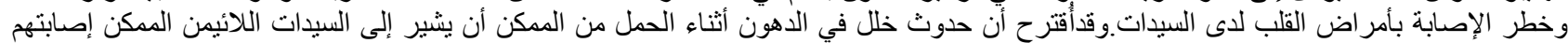

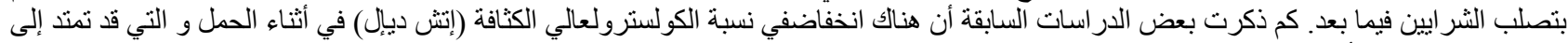
• البنو التعدالحمل الأول. هدفت هذه الدر اسة إلى دراسة تأثثر الحمل على دهون الدم أثناء الحمل الطبيعي ومتابعته أثناء الأثلاث المختلفة للحمل.

المرضى و طرق البحث:

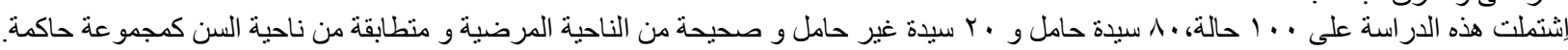
تم عمل الاتي لجميع الحالات: التاريخ المرضى الاتي ونجيع الفحص الإكلينيكي الكامل ، تخطيط القلب الكهربائي، فحص القلب بالموجات فوق الصوتية (الايكو) للتأكد من عدم و جود أمراض

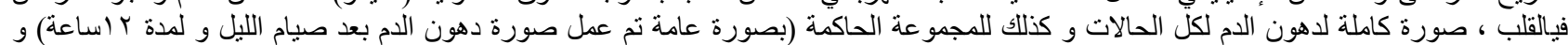

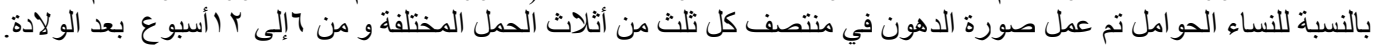

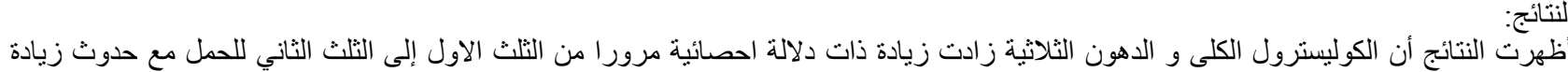

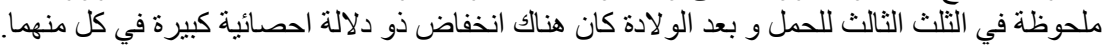

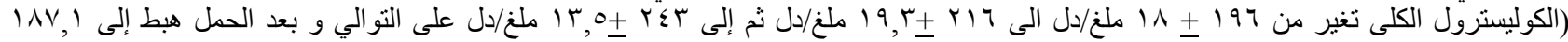

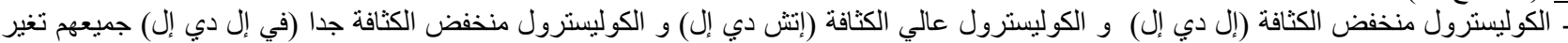

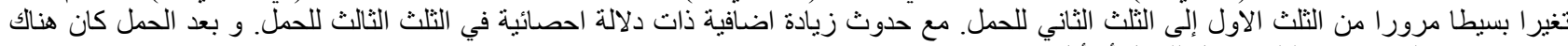

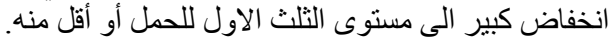

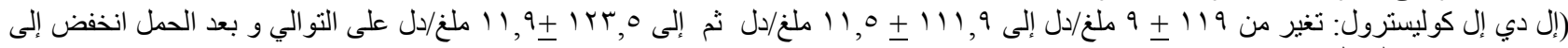

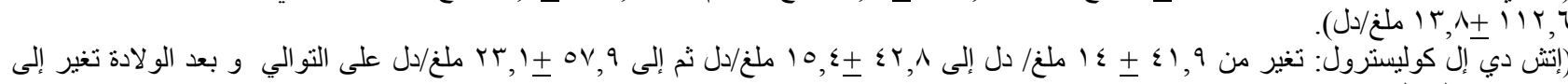
.

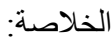

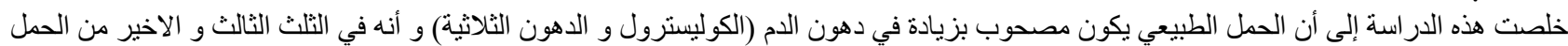

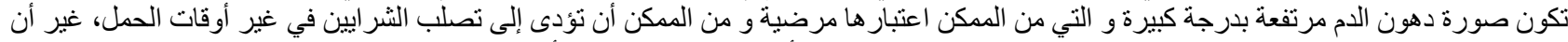

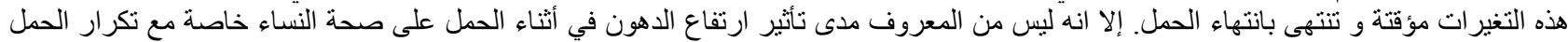

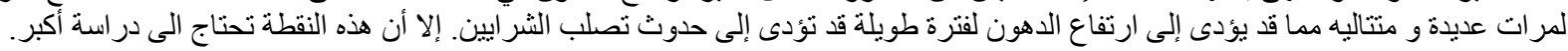

